\title{
Nocardia elegans sp. nov., a member of the Nocardia vaccinii clade isolated from sputum
}

Correspondence

A. F. Yassin

yassin@mibi03.meb.uni-bonn.de

\section{A. F. Yassin and S. Brenner}

Institut für Medizinische Mikrobiologie und Immunologie der Universität Bonn, 53127 Bonn, Germany

Two bacterial isolates from the sputa of a patient with a pulmonary infection were subjected to a polyphasic taxonomic study. Chemotaxonomic investigations revealed the presence of cell-wall chemotype IV and mycolic acids consistent with the profile for the genus Nocardia. Comparative 16S rRNA gene sequencing showed that these isolates constitute a distinct subline within the genus Nocardia, displaying 99.6-95.5\% sequence similarities with established species. However, DNA-DNA hybridization studies demonstrated unambiguously that the isolates are genealogically distinct from closely related species, namely Nocardia veterana and Nocardia africana, which show high levels of $16 \mathrm{~S}$ rRNA sequence similarity ( $99 \cdot 2$ and $99 \cdot 6 \%$ sequence similarity, respectively). On the basis of both phenotypic and phylogenetic evidence, it is proposed that these isolates be classified as a novel species of the genus Nocardia, for which the name Nocardia elegans sp. nov. is proposed. The type strain is IMMIB N-402 ${ }^{\top}\left(=\mathrm{CCUG}_{50200^{\top}}=\mathrm{CIP}\right.$ $\left.108553^{\top}\right)$.
The genus Nocardia represents a group of chemotaxonomically homogeneous, aerobic, Gram-positive, high-G + Ccontent organisms that form extensively branched substrate hyphae that fragment into rod-shaped to coccoid, nonmotile elements and belong phylogenetically to the Actinobacteria. In the past, the recognition of novel Nocardia species was problematic because of limitations in the taxonomic tests (primarily morphological and biochemical) used to identify these organisms. However, in recent years, the implementation of molecular identification methods, particularly 16S rRNA gene sequencing (Ruimy et al., 1994; Chun \& Goodfellow, 1995; Rainey et al., 1995), in parallel with improved phenotypic approaches has greatly facilitated the discovery of novel species and has resolved the taxonomy of isolates that were collectively assigned to the Nocardia asteroides complex (Yassin et al., 2000b, 2001). The genus Nocardia has undergone considerable expansion in the past few years, and at the time of writing over 40 species are recognized. The vast majority of these species have been isolated from human clinical specimens (Hamid et al., 2001; Yassin et al., 2000a, b, 2001) and, to a lesser extent, from animal (Isik et al., 1999a) and soil (Isik et al., 1999b; Albuquerque de Barros et al., 2003) sources. In the present study, the taxonomic status of two isolates, IMMIB N-402 ${ }^{\mathrm{T}}$

Published online ahead of print on 11 February 2005 as DOI 10.1099/ ijs.0.63570-0.

The GenBank/EMBL/DDBJ accession numbers for the 16S rRNA gene sequences of strains IMMIB N-402 ${ }^{\top}$ (=CCUG $50200^{\top}=\mathrm{CIP}$ $108553^{\top}$ ) and IMMIB N-403 (=CCUG 50201=CIP 108554) are AJ854057 and AJ854058, respectively. and IMMIB N-403, isolated from the sputa of a patient with a pulmonary infection, was determined using polyphasic taxonomic approaches. On the basis of the genotypic and phenotypic data reported here, the two isolates should be recognized as a novel species of the genus Nocardia for which the name Nocardia elegans sp. nov. is proposed.

Strains IMMIB N-402 ${ }^{\mathrm{T}}$ and IMMIB N-403 were cultured on brain-heart infusion (Becton Dickinson) agar to determine their morphological properties. The strains were biochemically characterized by using tests for the hydrolysis of complex substrates, as described previously (Gordon, 1966, 1967; Gordon \& Mihm, 1957), as well as tests to determine carbon-source utilization (according to Yassin et al., 1995). The presence of the isomeric form of diaminopimelic acid was tested by using the methods of Becker et al. (1964), while whole-cell sugars were determined by using the method of Lechevalier (1968). Lipids were extracted using acid methanolysis. Mycolic acids were detected by TLC as described by Minnikin et al. (1980); pyrolysis GC of the mycolates was performed according to Yassin et al. (1993a). Non-hydroxylated fatty acids were purified, identified and quantified by GC as described by Yassin (1988). Menaquinones were extracted, purified and identified according to Collins et al. (1977). Phospholipids were extracted, purified and identified as described previously (Yassin et al., 1993c).

DNA was isolated and purified as described previously (Yassin et al., 2000a). DNA-DNA hybridization studies were carried out by using the thermal renaturation method (Yassin et al., 1993b). Genomic DNA extraction, 
PCR-mediated amplification of $16 \mathrm{~S}$ rRNA genes and the purification of PCR products were carried out using procedures described previously (Rainey et al., 1996). Purified PCR products were sequenced using a Taq DyeDeoxy terminator cycle sequencing kit (Applied Biosystems) as described in the manufacturer's protocol. An Applied Biosystems 310 DNA genetic analyser was used for the electrophoresis of the sequence reaction products. The $16 \mathrm{~S}$ rRNA gene sequences of strains IMMIB N-402 ${ }^{\mathrm{T}}$ and IMMIB N-403, as well as those (retrieved from GenBank) of Nocardia species with validly published names, were added to the ARB database (Ludwig et al., 2004) and aligned using the integrated aligner software in the ARB package. The resulting alignment was corrected manually; evolutionary trees were inferred using maximum parsimony (Kluge \& Farris, 1969), neighbour joining (Saitou \& Nei, 1987) and maximum likelihood (Felsenstein, 1981). An evolutionary distance matrix was calculated using the corrections of Jukes \& Cantor (1969). The tree topology was evaluated according to the results of the neighbour-joining and maximum-likelihood analyses. The robustness of the phyletic lines was evaluated by using bootstrap analyses (Felsenstein, 1985) of neighbour-joining datasets for 1000 resamplings. The phylogenetic analyses were carried out using the ARB package.
Strains IMMIB N-402 ${ }^{\mathrm{T}}$ and IMMIB N-403 have morphological properties consistent with their assignment to the genus Nocardia. They are aerobic organisms that form hyphae that are Gram-positive and slightly acid-alcoholfast. The vegetative hyphae are orange in colour, well developed, with irregular branches penetrating the agar and bearing white aerial hyphae. At a late stage of growth the hyphae fragment into rod-shaped elements characteristic of nocardiae. The physiological properties of isolates IMMIB $\mathrm{N}-402^{\mathrm{T}}$ and IMMIB N-403 are cited in detail later, in the description of Nocardia elegans sp. nov. Biochemical differences between the isolates and some Nocardia species with validly published names (i.e. those examined in this study) are shown in Table 1.

Chemotaxonomically, isolates IMMIB N-402 ${ }^{\mathrm{T}}$ and IMMIB $\mathrm{N}-403$ contained chemical markers that support assignment of these micro-organisms to the genus Nocardia. The cell wall contains meso-diaminopimelic acid as well as arabinose and galactose (i.e. wall chemotype IV sensu Lechevalier \& Lechevalier, 1970). One-dimensional TLC of whole-cell acid methanolysates of strain IMMIB N-402 ${ }^{\mathrm{T}}$ and strain IMMIB $\mathrm{N}-403$ revealed the presence of two lipid spots, for each organism, with different flow rates on the chromatogram.

Table 1. Differential physiological characteristics of strains IMMIB N-402 ${ }^{\top}$, IMMIB N-403 and other significant Nocardia species with validly published names

Taxa are identified as follows: 1, IMMIB N-402 ${ }^{\mathrm{T}}$, IMMIB N-403; 2, N. veterana DSM $44445^{\mathrm{T}} ; 3$, N. africana SD $769^{\mathrm{T}} ; 4$, N. cerradoensis DSM $44546^{\mathrm{T}} ; 5$, N. vaccinii DSM $43285^{\mathrm{T}} ; 6, N$. nova ATCC $33726^{\mathrm{T}}$. All strains are positive for utilization of glucose as a carbon source and for hydrolysis of urea. All strains are negative for the following: hydrolysis of casein, elastin, gelatin, tyrosine, xanthine; utilization of cellobiose, raffinose, sorbitol, sucrose, meso-erythritol and myo-inositol as carbon sources; and utilization of acetamide, gelatin, proline and serine as simultaneous carbon and nitrogen sources. W, Weakly utilized after 3 weeks incubation.

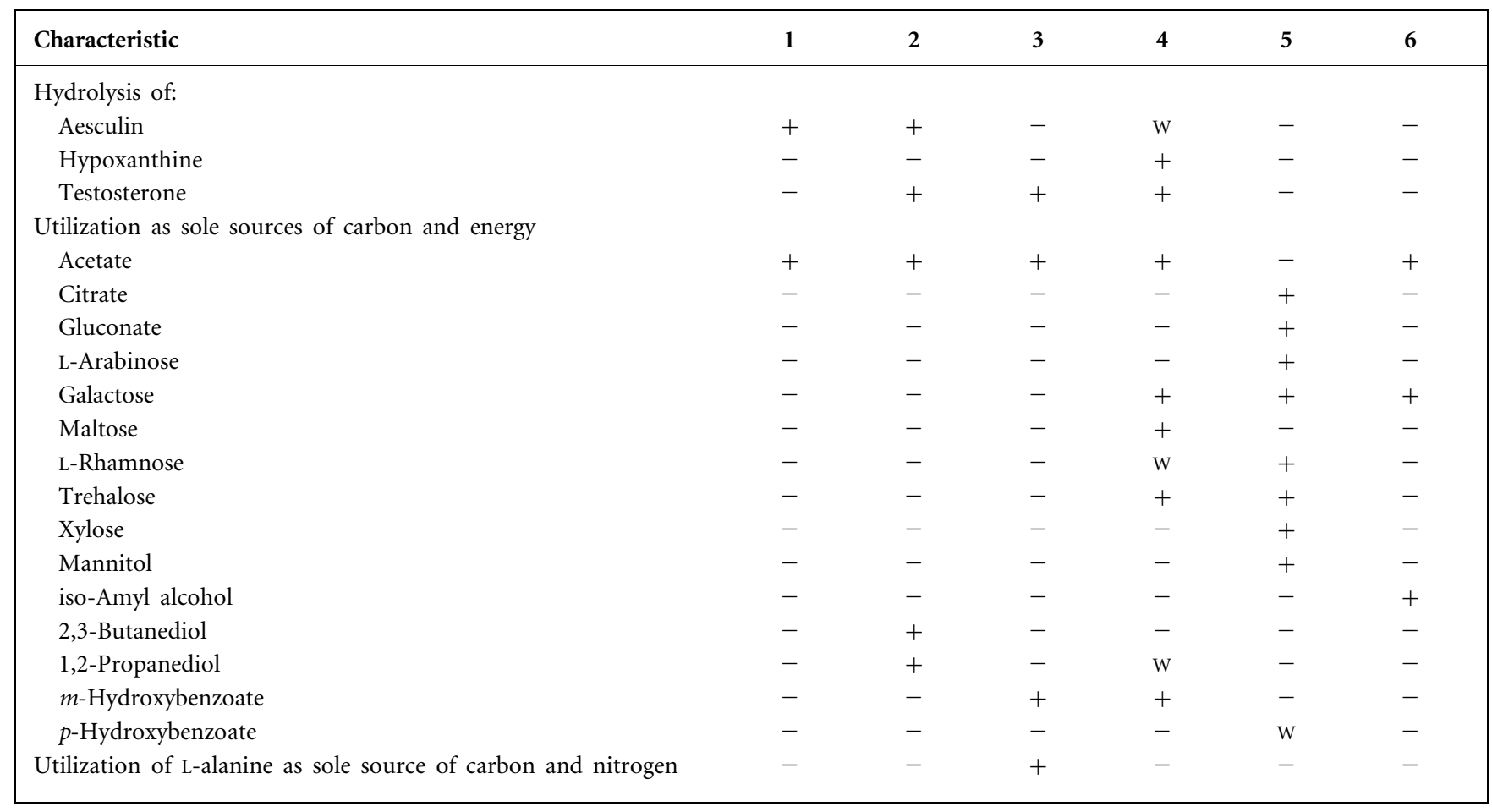


The lower spots correspond to mycolic acids, as identified by their $R_{\mathrm{F}}$ value $(0 \cdot 47)$, and the higher ones correspond to the non-hydroxylated fatty acids. Pyrolysis GC of the purified mycolic acid methyl esters from isolates IMMIB N$402^{\mathrm{T}}$ and IMMIB N-403 released fatty acid methyl esters of $\mathrm{C}_{16: 0}(33 \cdot 2 \%$ of total cleavage products of the mycolates from strain IMMIB $\left.\mathrm{N}-402^{\mathrm{T}}\right), \mathrm{C}_{18: 1}(27 \cdot 8 \%)$ and $\mathrm{C}_{18: 0}$ $(39.0 \%)$ as pyrolysis cleavage products. GC analyses of the non-hydroxylated fatty acid methyl esters revealed the presence of tetradecanoate $(0 \cdot 26 \%$ of total fatty acids from isolate IMMIB $\left.\mathrm{N}-402^{\mathrm{T}}\right)$, pentadecanoate $(0 \cdot 52 \%)$, cis-hexadecenoate $(0 \cdot 89 \%)$, hexadecanoate $(30.98 \%), 10$ methylhexadecanoate $(0 \cdot 1 \%)$, heptadecanoate $(1 \cdot 86 \%)$, 10 -methylheptadecanoate $(0 \cdot 39 \%)$, octadecenoate $(3 \cdot 85 \%)$, octadecanoate $(18 \cdot 15 \%)$, tuberculostearic acid (10-methyl octadecanoate, $38.91 \%)$, nonadecanoate $(0 \cdot 14 \%)$, eicosenoate $(0.95 \%)$, eicosanoate $(1.4 \%)$, heneicosenoate $(0 \cdot 61 \%)$ and heneicosanoate $(1 \cdot 0 \%)$ as the major cellular fatty acid methyl esters. Polar lipid analysis showed that strains IMMIB N-402 ${ }^{\mathrm{T}}$ and IMMIB N-403 contain phosphatidylethanolamine, phosphatidylinositol, phosphatidylinositol mannoside and diphosphatidylglycerol as the characteristic phospholipids (i.e. phospholipid type PII sensu Lechevalier et al., 1977). Mass-spectral analysis of the respiratory quinones showed that isolate IMMIB N-402 and isolate IMMIB N-403 possess hexahydrogenated menaquinones with eight isoprene units in which the two terminal isoprene moieties are cyclized. The main component corresponds to $\mathrm{MK}-8\left(\mathrm{H}_{6}\right)$ and the minor component corresponds to 2,3-epoxy-MK-8 $\left(\mathrm{H}_{6}\right)$. These chemotaxonomic similarities to Nocardia species with validly published names are supported by the high levels of $16 \mathrm{~S}$ rRNA gene sequence similarity observed between isolates IMMIB $\mathrm{N}-402^{\mathrm{T}}$ and IMMIB $\mathrm{N}-403$ and members of the genus Nocardia.

To ascertain the phylogenetic position of strains IMMIB N$402^{\mathrm{T}}$ and IMMIB N-403, their almost-complete $16 \mathrm{~S}$ rRNA gene sequences [ $1483 \mathrm{nt} ; 96 \cdot 1 \%$ of the Escherichia coli sequence (Brosius et al., 1978)] were determined in this study and subjected to a comparative analysis. The $16 \mathrm{~S}$ rRNA gene sequence comparison clearly shows that strains IMMIB N-402 ${ }^{\mathrm{T}}$ and IMMIB N-403 are members of the family Nocardiaceae (Stackebrandt et al., 1997). The high values for the $16 \mathrm{~S}$ rRNA gene sequence similarities to other previously described members of the genus Nocardia $(95 \cdot 5-99 \cdot 6 \%)$ support the addition of strains IMMIB N$402^{\mathrm{T}}$ and IMMIB N-403 to this genus. There were significantly lower levels of similarity with other Actinomycetales taxa (data not shown). The highest sequence similarities were shown with Nocardia nova, Nocardia vaccinii, Nocardia cerradoensis, Nocardia veterana and Nocardia africana $(98 \cdot 3,98 \cdot 5,98 \cdot 7,99 \cdot 2$ and $99 \cdot 6 \%$ sequence similarity, respectively). A tree constructed using the neighbour-joining method, depicting the phylogenetic placement of strains IMMIB N-402 ${ }^{\mathrm{T}}$ and IMMIB N-403 within a subset of the genus Nocardia, is shown in Fig. 1. It is evident from the tree that the two isolates represent a distinct subline within the genus Nocardia that is associated with $N$. africana, $N$. veterana, $N$. cerradoensis and $N$. vaccinii. These results suggest that strains IMMIB $\mathrm{N}-402^{\mathrm{T}}$ and IMMIB N-403 belong to a genetically distinct Nocardia species showing close relatedness with $N$. africana, $N$. veterana, $N$. vaccinii and $N$. cerradoensis. These sequence similarities are too high to allow the definition of a novel species, since values below $97 \%$ and/or genomic DNA reassociation values below $70 \%$ are considered necessary for the establishment of a novel bacterial species (Stackebrandt \& Goebel, 1994). In view of the high levels of $16 \mathrm{~S}$ rRNA sequence similarities between isolates IMMIB $\mathrm{N}-402^{\mathrm{T}}$ and IMMIB N-403 and some Nocardia species, chromosomal DNA-DNA hybridization studies were performed to establish whether strains IMMIB $\mathrm{N}-402^{\mathrm{T}}$ and IMMIB N-403 represent distinct species. Strains IMMIB N-402 ${ }^{\mathrm{T}}$ and IMMIB N-403 displayed low levels of DNA-DNA reassociation with the type strains of $N$. africana SD $769^{\mathrm{T}}(30 \cdot 2$ and $33 \cdot 6 \%$, respectively) and $N$. veterana DSM $44445^{\mathrm{T}}(33.6 \%$ and $27 \cdot 5 \%$, respectively), results which are below the cut-off point recommended by Wayne et al. (1987) for the circumscription of bacterial genomic species, and confirm the separation of isolates IMMIB N$402^{\mathrm{T}}$ and IMMIB N-403 from their nearest phylogenetic neighbours.

The genus Nocardia contains a number of species for which numerous distinctive characteristics have been described that fully justify their classification in separate species but that exhibit only limited $16 \mathrm{~S}$ rRNA divergence. For instance, the $16 \mathrm{~S}$ rRNA of N. vaccinii is $98 \cdot 5-98 \cdot 7 \%$ similar to that of $N$. africana, though the distinction between the two species has been convincingly illustrated by virtue of different characteristics and did not require the determination of DNA hybridization values (Hamid et al., 2001). More critical examples are N. veterana and $N$. africana, the $16 \mathrm{~S}$ rRNA gene sequences of which are $99 \cdot 3 \%$ similar, whereas the total labelled genomic DNA of the two species exhibited only $28.8 \%$ homology. Similar situations were found for Nocardia brevicatena and Nocardia paucivorans, which have a $16 \mathrm{~S}$ rRNA similarity value of $99.6 \%$ but $61.9 \%$ DNADNA relatedness (Yassin et al., 2000a), and for Nocardia carnea and Nocardia flavorosea, which have a $16 \mathrm{~S}$ rRNA similarity value of $99 \cdot 2 \%$ but $5 \cdot 0 \%$ DNA-DNA relatedness (Chun et al., 1998). Given the $1 \cdot 4,1 \cdot 5$ and $1.8 \%$ sequence divergence between isolates IMMIB N-402 ${ }^{\mathrm{T}}$ and IMMIB $\mathrm{N}-403$ and their closest relatives, N. cerradoensis, N. vaccinii and $N$. nova, respectively, and the biochemical tests (Table 1) differentiating isolates IMMIB $\mathrm{N}-402^{\mathrm{T}}$ and IMMIB N-403 from the latter three species, it is reasonable to define a novel species. The chemical (and morphological) data clearly indicate that the isolates belong to the genus Nocardia. The 16S rRNA gene sequencing, the DNA-DNA pairing and the biochemical results indicate that the two isolates are similar and represent a novel species when compared with the type strains of Nocardia species with validly published names. Thus, on the basis of the results of the polyphasic taxonomic study reported here, we consider that isolates IMMIB N-402 ${ }^{\mathrm{T}}$ and IMMIB N-403 represent 


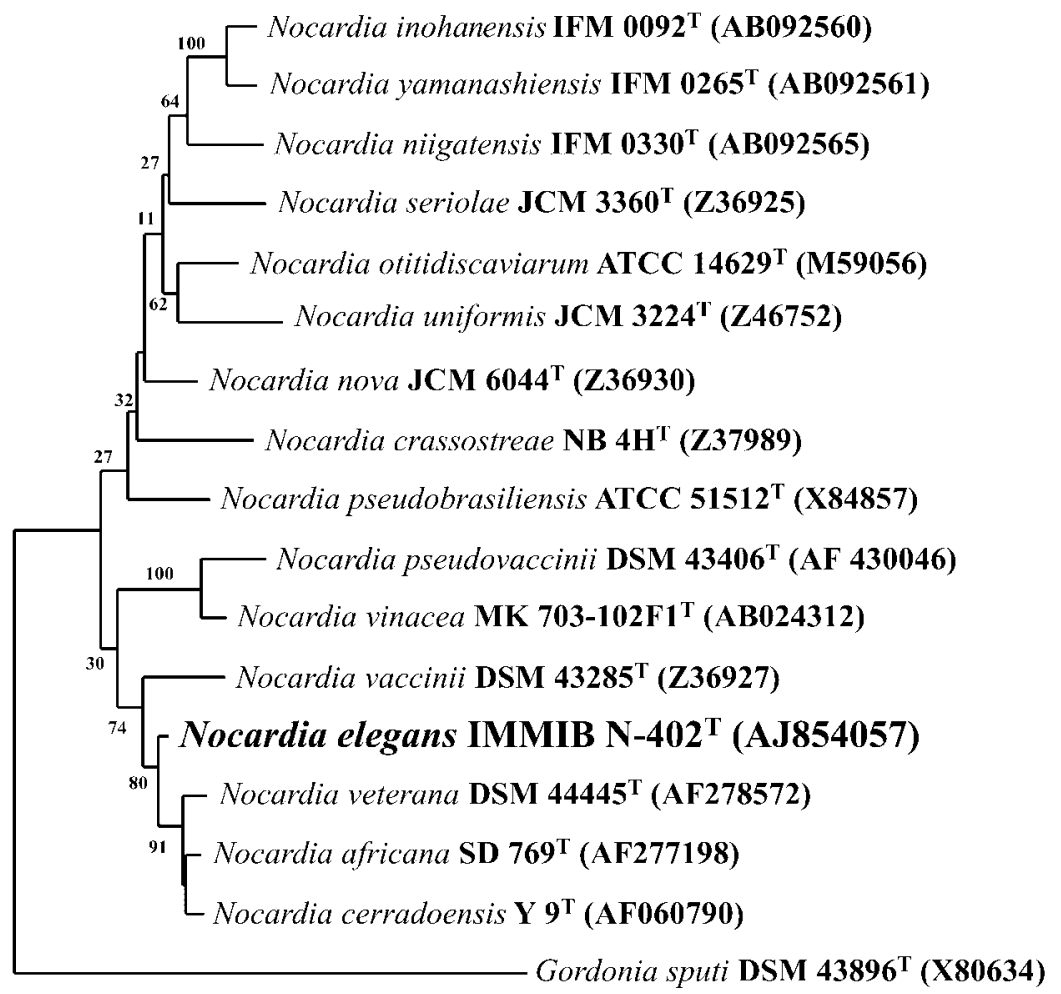

$10.0 \%$
Fig. 1. Neighbour-joining tree showing the position of the type strain of Nocardia elegans, strain IMMIB N-402 ${ }^{\top}$ (= CCUG $50200^{\top}=\mathrm{CIP} 108553^{\top}$ ), within the radiation of species of the genus Nocardia. The tree was based on a comparison of sequences that were at least $90 \%$ complete (with regard to the $E$. coli sequence). Bar, $10.0 \%$ sequence divergence. one species and merit classification as a novel species of the genus Nocardia, for which the name Nocardia elegans sp. nov. is proposed, with IMMIB N-402 ${ }^{\mathrm{T}}$ as the type strain.

\section{Description of Nocardia elegans sp. nov.}

Nocardia elegans (e'le.gans. L. adj. elegans fastidious - with respect to utilization of nutrients).

The hyphae are Gram-positive and partially acid-alcoholfast. Vegetative hyphae are orange in colour, well developed with irregular branches penetrating the agar and bear white aerial hyphae. At a late stage of growth the hyphae fragment into rod-shaped elements. Grows at temperatures in the range $22-42{ }^{\circ} \mathrm{C}$. The organism possesses the salient chemotaxonomic characteristics of the genus Nocardia. Its mycolic acids are cleaved, upon pyrolysis, releasing fatty acids $\mathrm{C}_{16: 0}$, $\mathrm{C}_{18: 1}$ and $\mathrm{C}_{18: 0}$ with $\mathrm{C}_{18: 0}$ as the major cleavage product. Hydrolyses aesculin, testosterone and urea but not adenine, casein, elastin, gelatin, guanine, hypoxanthine, tyrosine or xanthine. Assimilates acetate and glucose as carbon sources, but not adonitol, adipate, iso-amyl alcohol, arabinose, 2,3butanediol, cellobiose, citrate, meso-erythritol, galactose, gluconate, $m$-hydroxybenzoate, $p$-hydroxybenzoate, myoinositol, lactate, lactose, maltose, mannitol, melezitose, 1,2propanediol, raffinose, rhamnose, sorbitol, sucrose, trehalose or xylose. Does not utilize acetamide, arginine, gelatin, ornithine, proline or serine as simultaneous carbon and nitrogen sources.

The type strain of Nocardia elegans is strain IMMIB N-402 $\left(=\right.$ CCUG $50200^{\mathrm{T}}=$ CIP $\left.108553^{\mathrm{T}}\right)$.

\section{Acknowledgements}

We thank Professor Dr Hans Georg Trüper for advice on the species name.

\section{References}

Albuquerque De Barros, E. V. S., Manfio, G. P., Ribeiro Maitan, V., Mendes Bataus, L. A., Kim, S. B., Maldonado, L. A. \& Goodfellow, M. (2003). Nocardia cerradoensis sp. nov., a novel isolate from Cerrado soil in Brazil. Int J Syst Evol Microbiol 53, 29-33.

Becker, B., Lechevalier, M. P., Gordon, R. E. \& Lechevalier, H. A. (1964). Rapid differentiation between Nocardia and Streptomyces by paper chromatography of whole cell hydrolysates. Appl Microbiol 12, 421-423.

Brosius, J., Palmer, M. L., Kennedy, P. J. \& Noller, H. F. (1978). Complete nucleotide sequence of the $16 \mathrm{~S}$ ribosomal RNA gene from Escherichia coli. Proc Natl Acad Sci U S A 75, 4801-4805.

Chun, J. \& Goodfellow, M. (1995). A phylogenetic analysis of the genus Nocardia with $16 \mathrm{~S}$ rRNA gene sequences. Int J Syst Bacteriol 45, 240-245. 
Chun, J., Seong, C.-N., Bae, K. S., Lee, K.-J., Kang, S.-O., Goodfellow, M. \& Hah, Y. C. (1998). Nocardia flavorosea sp. nov. Int J Syst Bacteriol 49, 901-905.

Collins, M. D., Pirouz, T., Goodfellow, M. \& Minnikin, D. E. (1977). Distribution of menaquinones in actinomycetes and corynebacteria. J Gen Microbiol 100, 221-230.

Felsenstein, J. (1981). Evolutionary trees from DNA sequences: a maximum likelihood approach. J Mol Evol 17, 368-376.

Felsenstein, J. (1985). Confidence limits on phylogenies: an approach using the bootstrap. Evolution 39, 783-791.

Gordon, R. E. (1966). Some criteria for the recognition of Nocardia madurae (Vincent) Blanchard. J Gen Microbiol 45, 355-364.

Gordon, R. E. (1967). The taxonomy of soil bacteria. In The Ecology of Soil Bacteria, pp. 293-321. Edited by T. R. G. Gray \& B. Parkinson. Liverpool: University Press.

Gordon, R. E. \& Mihm, J. M. (1957). A comparative study of some strains received as nocardiae. J Bacteriol 73, 15-27.

Hamid, E. M., Maldonado, L., Sharaf Eldin, S. G., Mohamed, F. M., Saeed, S. N. \& Goodfellow, M. (2001). Nocardia africana sp. nov., a new pathogen isolated from patients with pulmonary infections. $J$ Clin Microbiol 39, 625-630.

Isik, K., Chun, J., Hah, Y. C. \& Goodfellow, M. (1999a). Nocardia salmonicida nom. rev., a fish pathogen. Int J Syst Bacteriol 49, 833-837.

Isik, K., Chun, J., Hah, Y. C. \& Goodfellow, M. (1999b). Nocardia uniformis nom. rev. Int J Syst Bacteriol 49, 1227-1230.

Jukes, T. H. \& Cantor, C. R. (1969). Evolution of protein molecules. In Mammalian Protein Metabolism, pp. 21-132. Edited by H. N. Munro. New York: Academic Press.

Kluge, A. G. \& Farris, F. S. (1969). Quantitative phyletics and the evolution of anurans. Syst Zool 18, 1-32.

Lechevalier, M. P. (1968). Identification of aerobic actinomycetes of clinical importance. J Lab Clin Med 71, 934-944.

Lechevalier, M. P. \& Lechevalier, H. A. (1970). Chemical composition as a criterion in the classification of aerobic actinomycetes. Int J Syst Bacteriol 20, 435-443.

Lechevalier, M. P., de Bievre, C. \& Lechevalier, H. A. (1977). Chemotaxonomy of aerobic actinomycetes: phospholipid composition. Biochem Syst Ecol 5, 249-260.

Ludwig, W., Strunk, O., Westram, R. \& 29 other authors (2004). ARB: a software environment for sequence data. Nucleic Acids Res 32, 1363-1371.

Minnikin, D. E., Hutchinson, I. G., Caldicott, A. B. \& Goodfellow, M. (1980). Thin-layer chromatography of methanolysates of mycolic acid-containing bacteria. J Chromatogr 188, 221-223.

Rainey, F. A., Burghardt, J., Kroppenstedt, R. M., Klatte, S. \& Stackebrandt, E. (1995). Phylogenetic analysis of the genera Rhodococcus and Nocardia and evidence for the evolutionary origin of the genus Nocardia from within the radiation of Rhodococcus species. Microbiology 141, 523-528.
Rainey, F. A., Ward-Rainey, N., Kroppenstedt, R. M. \& Stackebrandt, E. (1996). The genus Nocardiopsis represents a phylogenetically coherent taxon and a distinct actinomycete lineage: proposal of Nocardiopsiaceae fam. nov. Int J Syst Bacteriol 46, 1088-1092.

Ruimy, R., Boiron, P., Boivin, V. \& Christen, R. (1994). A phylogeny of the genus Nocardia deduced from the analysis of small-subunit ribosomal DNA sequences, including transfer of Nocardia amarae to the genus Gordona as Gordona amarae comb. nov. FEMS Microbiol Lett 123, 261-268.

Saitou, N. \& Nei, M. (1987). The neighbour-joining method: a new method for reconstructing phylogenetic trees. Mol Biol Evol 4, 406-425.

Stackebrandt, E. \& Goebel, B. M. (1994). Taxonomic note: a place of DNA-DNA reassociation and 16S rRNA sequence analysis in the present species definition in bacteriology. Int J Syst Bacteriol 44, 846-849.

Stackebrandt, E., Rainey, F. A. \& Ward-Rainey, N. L. (1997). Proposal for a new hierarchic classification system, Actinobacteria classis nov. Int J Syst Bacteriol 47, 479-491.

Wayne, L. G., Brenner, D. J., Colwell, R. R. \& 9 other authors (1987). Report of the ad hoc committee on recognition of approaches to bacterial systematics. Int J Syst Bacteriol 37, 463-464.

Yassin, A. F. (1988). Chemotaxonomic Untersuchungen zur vereinfachten Differenzierung und Identifizierung von aeroben Aktinomyzeten und Mykobakterien. Inaaugural-Dissertation zur erlangung des Doktorgrades der Mathematische-Naturwissenschaftlichen Fakultät der Rheinischen friedrich-Wilhelms-Universität Bonn.

Yassin, A. F., Binder, C. \& Schaal, K. P. (1993a). Identification of mycobacterial isolates by thin-layer and capillary gas-liquid chromatography under diagnostic routine conditions. Zentralbl Bakteriol 278, 34-48.

Yassin, A. F., Galinski, E. A., Wohlfarth, A., Jahnke, K.-D., Schaal, K. P. \& Trüper, H. G. (1993b). A new actinomycete species, Nocardiopsis lucentensis sp. nov. Int J Syst Bacteriol 43, 266-271.

Yassin, A. F., Haggenei, B., Budzikiewicz, H. \& Schaal, K. P. (1993c). Fatty acid and polar lipid composition of the genus Amycolatopsis: application of fast atom bombardment mass spectrometry to structure analysis of underivatized phospholipids. Int J Syst Bacteriol 43, 414-420.

Yassin, A. F., Rainey, F. A., Brzezinka, H., Burghardt, J., Lee, H. L. \& Schaal, K. P. (1995). Tsukamurella inchonensis sp. nov. Int J Syst Bacteriol 45, 522-527.

Yassin, A. F., Rainey, F. A., Burghardt, J., Brzezinka, H., Mauch, M. \& Schaal, K. P. (2000a). Nocardia paucivorans sp. nov. Int J Syst Evol Microbiol 50, 803-809.

Yassin, A. F., Rainey, F. A., Mendrock, U., Brzezinka, H. \& Schaal, K. P. (2000b). Nocardia abscessus sp. nov. Int J Syst Evol Microbiol 50, 1487-1493.

Yassin, A. F., Rainey, F. A. \& Steiner, U. (2001). Nocardia cyriacigeorgici sp. nov. Int J Syst Evol Microbiol 51, 1419-1423. 